\title{
APPLICATION OF PROSTAGLANDIN SYNTHETASE IN PREPARATIVE OXIDATION OF POLYENIC ACIDS TO PROSTAGLANDIN DRUGS *
}

Biochemical synthesis was the first and simplest process for the preparation of prostaglandins (PG) needed in increasing quantities for biological studies after the elucidation of their structure in the early sixties $\left[{ }^{1,2}\right]$. Soon the limitations of the biochemical process (low capacity, incompatibility with analog synthesis) were understood and synthetic activities were directed towards semisynthetic and total chemical preparation [ $\left.{ }^{3}\right]$. With the aid of the latter, at the beginning of the seventies the commercial production of PG began to correspond to the growing demand for biological studies, human and veterinary medicine and animal breeding. Up to now, more than twenty drugs [4,5] have been registered on the basis of PG and their analogs used in million doses.

Meanwhile research work on the characterization of PG synthetase was continued, and from time to time attempts were made to increase the capacity of the biochemical process $\left[{ }^{6-8}\right]$. Attention was also paid to biosynthesis using microorganisms $[3,9,10]$.

In this paper we have summarized the results of the research work aimed at developing high-capacity biochemical PG synthesis and assessing future prospects.

Our attention was mainly devoted to PGE, particularly to $\mathrm{PGE}_{2}$. PGE can be easily converted chemically to PGF of high yields and further to PGI.

The total efficiency of biochemical synthesis depends on the characteristics of the biocatalyst and reaction system, resources of enzyme, parameters of preparative process, and the existence of proper drug forms. Let us focus our attention upon those items.

Characterization of biocatalyst and reaction system. The formation of PG is catalyzed by at least two enzymes, PGH synthetase (dioxygenase) and PGH convertase (PGE isomerase, etc., Table 1). The rate-limiting enzyme, dioxygenase, is a unique enzyme catalyzing oxidation and reduction in one sequence of molecular changes of the fatty acid substrate. It is a membrane-bound hemeprotein consisting of two polypeptide chains with a molecular mass of about $70 \mathrm{kD}$. The heme is reversibly bound to an apoenzyme. The enzyme activity depends on the S-S bonds, serine-like $\mathrm{OH}$ groups and an imidazole ring of histidine. These characteristics and also the spectral data are consistent with typical hemeproteins. Unlike hemoglobin, the holoenzyme is insensitive to carbon monoxide.

* Lecture held at the second All-Union conference «Synthetic and applied studies of prostaglandins», Ufa, October 1984. 
PGH synthetase (EC 1.14.99.1) isolated from sheep vesicular glands

yield, $\%$ of activity

purification ratio (-fold)

polypeptide chain molecular mass, $\mathrm{kD}$

quantity of chains

sequence of amino acids

quantity of hemes per chain

Heme-apoferment complex

$K_{D}, M$

$E_{412}, \mathrm{mM}^{-1} \cdot \mathrm{cm}^{-1}$

$E_{280}, \mathrm{mM}^{-1} \cdot \mathrm{cm}^{-1}$

$K_{D} \mathrm{CN}, \mathrm{M}$

CO

Concentration of activator (ROOH), M

Sensitivity to dithiothreitol $+\mathrm{N}$-ethylmaleimide aspirin

glutaric aldehyde

diethylpyrocarbonate

Dioxygenase activity, $\mu \mathrm{m}$ of acid/mg $\cdot \mathrm{min}$

optimal $\mathrm{pH}$

Michaelis constant $\left(K_{M}\right), M$

for arachidonic acid

for $\mathrm{O}_{2}$

for hydroquinone

$k_{\text {cat }} / k_{i n}$ (for acid)

$K_{J}(8,12,14$-eicosatrienoic acid), $M$

Peroxidase activity

$\mu \mathrm{m}$ of $\mathrm{H}_{2} \mathrm{O}_{2} / \mathrm{mg} \cdot \mathrm{min}$

$10-30$
$>65$
70
2
DAERAAOPEAPAPV
1

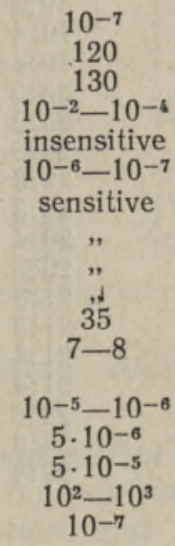

3

PGE isomerase (EC 5.3.99.2) isolated from bovine vesicular glands

yield, $\%$ of activity

coenzyme

activity, $\mu \mathrm{m} / \mathrm{mg} \cdot \mathrm{min}$

GS -7

2

* For detailed literature, see $\left[{ }^{11,}{ }^{17}\right]$.

The oxidation of fatty acid substrate is a free radical reaction, being similar to that of plant lipoxygenases. The specificity for polyenic acid with the methylene-interrupted cis-double-bond system is considerably high (Table 2). The $\mathrm{C}_{20} \quad\left(\mathrm{C}_{19}\right)$ w 6 acids are strongly favoured. The methyl branch interferes with the PG-formation, and this effect depends on the location of the branch in the chain. Chemically various groups in the $\alpha$ position to the carboxyl group inhibit the conversion of the substrate more strongly than the methyl group. It is accepted that the fatty acid substrate is bound to the enzyme before oxygen. the second substrate. This is the case for cytochrome P-450 as well [24].

In the reductive step, a third substrate is needed, viz. the electron donor. The specificity of the donor is very low: biologically active amines, phenols, inorganic salts, etc. act almost similarly. The structure of the co-oxidation products is donor-dependent.

The mechanism of the dioxygenase reaction seems to be parallel to that of autoxidation [11]. The main role of the enzyme is to ensure the translocation of the side chains of endoperoxide $\left[{ }^{25}\right]$ and an approximately $10^{5}$-fold acceleration of the reaction.

The characteristic feature of dioxygenase is its self-destruction during catalysis $\left[{ }^{26}\right]$. This phenomenon belongs to mechanism-based enzyme inactivations $\left[{ }^{27}\right]$, and there is no effective way of avoiding this process entirely.

Various approaches have been proposed for regulating dioxygenase activity in the living cell. The question has not been solved as yet, and 
Substrate specificity of PG synthetase $\left[{ }^{20-23}\right]$

\begin{tabular}{|c|c|c|c|}
\hline Precursor & $\begin{array}{c}\text { Con- } \\
\text { version, } \\
\%\end{array}$ & $\begin{array}{c}\text { Precursor } \\
\text { R-20:3 w } 6\end{array}$ & $\begin{array}{c}\text { Con- } \\
\text { version, } \\
\%\end{array}$ \\
\hline $\begin{array}{l}18: 3 \text { w } 4 \\
10: 3 \text { w } 6 \\
18: 4 \text { w } 6 \\
19: 3 \text { w } 5 \\
19: 3 \text { w } 6 \\
19: 4 \text { w } 5 \\
19: 4 \text { w } 6 \\
20: 3 \text { w } 5 \\
20: 3 \text { w } 6 \\
20: 3 \text { w } 7 \\
20: 3 \text { w } 8 \\
20: 3 \text { w } 9 \\
20: 4 \text { w } 6 \\
20: 5 \text { w } 3 \\
21: 3 \text { w } 6 \\
21: 3 \text { w } 7 \\
21: 4 \text { w } 6 \\
21: 4 \text { w } 7 \\
22: 3 \text { w } 6 \\
22: 3 \text { w } 8 \\
22: 4 \text { w } 6\end{array}$ & $\begin{array}{r}-7 \\
15 \\
2 \\
85 \\
44 \\
58 \\
3 \\
96 \\
25 \\
- \\
100 \\
7 \\
51 \\
30 \\
35 \\
52 \\
7 \\
34\end{array}$ & 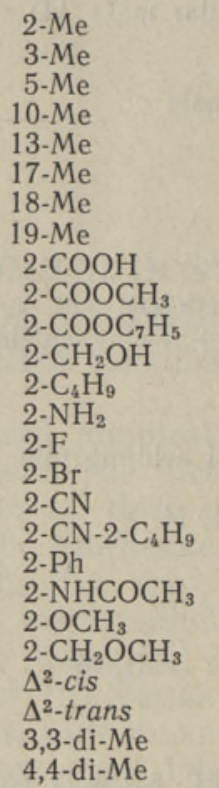 & $\begin{array}{r}70 \\
35 \\
48 \\
10 \\
3 \\
12 \\
9 \\
20 \\
1 \\
14 \\
14 \\
13 \\
19 \\
1 \\
33 \\
37 \\
28 \\
14 \\
24 \\
3 \\
24 \\
35 \\
52 \\
35 \\
28 \\
1\end{array}$ \\
\hline
\end{tabular}

it is not known whether the inactivated dioxygenase in the living cell is «wounded» or «dead».

Resources of dioxygenase. The dioxygenase is a key enzyme in the biochemical and semisynthetic PG synthesis. By the way, the endoperoxide formation with proper stereochemistry from simple reagents is so far beyond any synthetic method.

During the recent 20 years no great success has been achieved in increasing the resources of $\mathrm{PG}$ endoperoxide synthetase. The seminal vesicles of ovines and bovines remain the most accessible raw materials. Therefore the use of DNA recombinant methods for cloning endoperoxide-synthetase-producing microorganisms is highly desirable.

In relevant literature, there is strong evidence of PG synthesis in plants $\left[{ }^{28-30}\right]$. This is probably the result of the action of various plant lipoxygenases on the acid substrate. If a suitable type of lipoxygenase should be found, then the cultivation of proper plant cells might yield

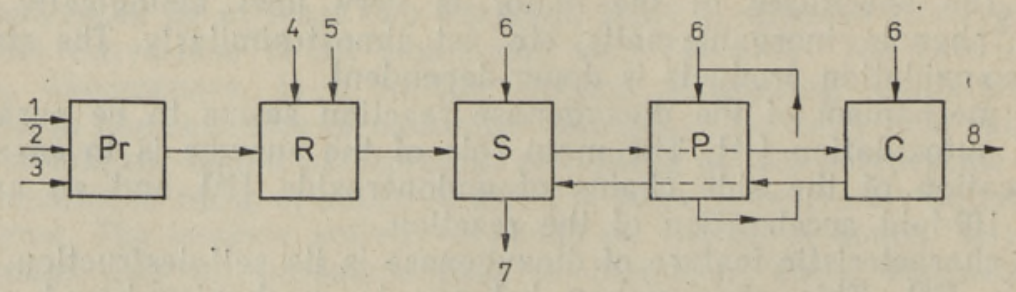

Fig. 1. Main steps of biochemical synthesis of PG. $\mathrm{Pr}-$ preparation, $\mathrm{R}-$ incubation, $\mathrm{S}$ - separation, P - purification, C - concentration. 1 - vesicular glands, 2 - buffer, 3 - cofactors, $4-$ fatty acid substrate, 5 - air, $6-$ solvents, 7 - wastes, $8-$ product. 
Fig. 2. Specific yield of $\mathrm{PGE}_{2}$ (1) and degree of conversion of arachidonic acid (2) vs. protein concentration.

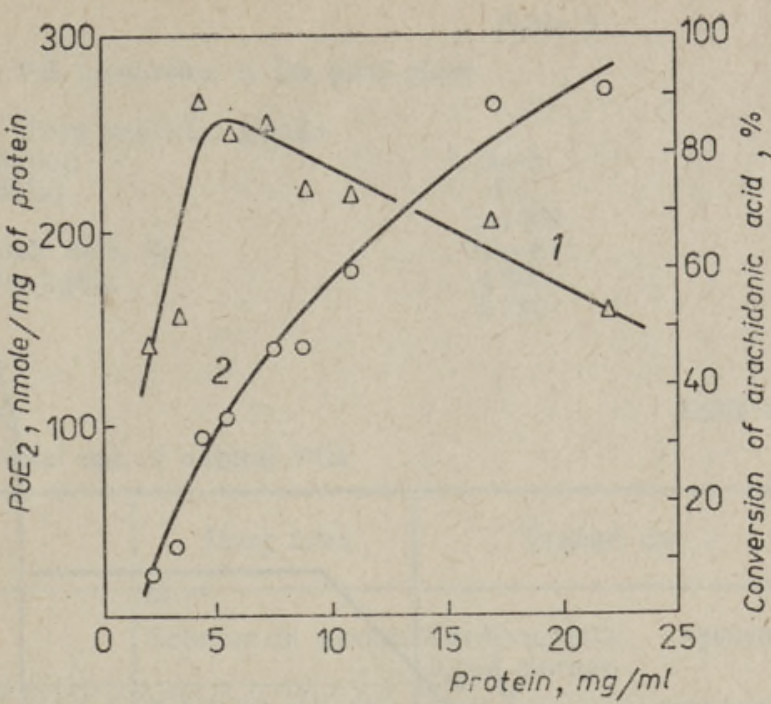

a catalyst for biochemical oxidations (or direct biosynthesis could be performed).

Parameters of the preparative process. The most important features in designing a biochemical process seem to be the proper biocatalyst, its working conditions, and possibilities for product separation and purification (Fig. 1).

The dioxygenase activity determines the product concentration, and the latter together with the physical state of catalyst is decisive in the subsequent separation procedure.

In modern enzyme technology enzyme immobilization is widely used. In many cases it stabilizes the catalyst and enables recycling. Nowadays one can find many examples of immobilization for all classes of enzymes to various carriers, including oxygenases and PG-dioxygenase $\left[{ }^{8}\right]$. So far there is, however, no case of successful protection against suicidal inactivation. As long as the self-destruction of the biocatalyst is not markedly decreased, the use of immobilized dioxygenase is economically inacceptable. In this case the use of synthetase in the form of tissue homogenate with a specific activity of about $0.1 \mu$ mole arachidonic $\mathrm{acid} / \mathrm{mg}$ protein $\mathrm{min}$ is advantageous. The recycling of microsomal protein [ $\left.{ }^{6}\right]$ appeared to be far less favourable.

The most important characteristics of the reactor are product capacity per unit of reactor volume, specific yield of the product and the degree of conversion of the fatty acid substrate. As can be seen from Fig. 2, a compromise between the values of these parameters is needed. It is to be pointed out that for each protein concentration there exists an optimal concentration of the fatty acid substrate for obtaining maximal specific yield. For the homogenate protein it is about $0.4-0.5$ $\mu \mathrm{mole} / \mathrm{mg}$.

It should be borne in mind that the preparative synthesis conditions are quite different from those used for the in vitro enzyme studies. The latter system is usually homogeneous, and the concentration of organic components is on a micromole level or lower. There is enough oxygen dissolved in the reaction medium equilibrated with air for a reaction to occur. The preparative conversion of the fatty acid substrate takes place in a multiphase system, and the concentration of most components is on a millimole level. Therefore the recommendations made on the basis of measurements in a polarographic unit or a spectral cuvette must be checked very carefully until any statement about pre- 


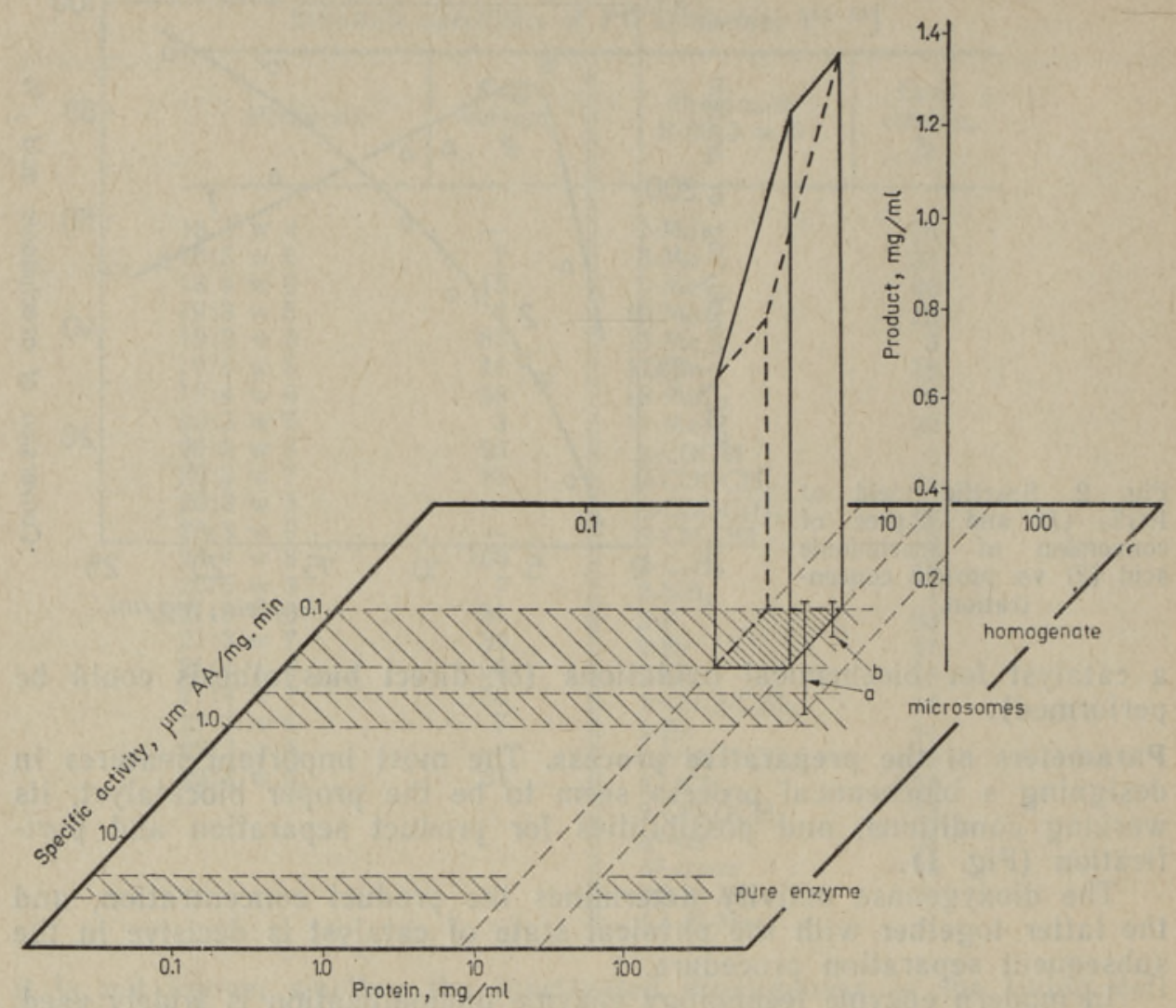

Fig. 3. Choice of biocatalyst and volume capacity of reactor. Specific activity ( $\mu$ mole arachidonic acid/mg protein $\mathrm{min})$ and protein concentration $(\mathrm{mg} / \mathrm{ml})$ vs. product concentration $(\mathrm{mg} / \mathrm{ml})$. The cut rectangle shows parameters of our process, $a, b-$ according to $[3,6]$.

parative process can be made. This concerns the use of organic solvents or solutions with a high ionic power. From this point of view, preparative studies $[3,6]$ played an important role in further development. However, the product yields (mainly $\mathrm{PGE}_{2}$ ) remained low (below $0.3 \mathrm{mg} / \mathrm{ml}$ ).

This is why a reinvestigation of all parameters of the system, including cofactors, nonionic detergents and organic solvents, was undertaken. After that, the dispersity of the system was guaranteed.

Due to these studies, the $\mathrm{PGE}_{2}$ yield of about one $\mathrm{mg} / \mathrm{ml}$ was obtained in reactor volume (Fig. 3).

On the present technological level, separation of protein from the reaction mixture remains critical for further dilution of the reaction system. Conventional precipitation with organic solvents results in a further $2-3$-fold increase in volume followed by a strictly controlled evaporation of the solvent added. For further product purification onestep chromatography and crystallization are quite sufficient. Some characteristics of the process are given in Table 3 .

In fact, it is one-pot synthesis, and in a 10-litre working-volume reactor one can obtain amounts of $\mathrm{PGE}_{2}$ (or $\mathrm{E}_{1}$ ) on a $\mathrm{kg}$ level per year.

During the recent six years, this process has been in use for the production of natural PGs for biological and medical studies [ $\left.{ }^{31}\right]$, and in a near future its whole capacity will be used to produce PGs for wider use in medicine. 
Data on the PG production in the pilot plant

Product yield, $\mathrm{g} / \mathrm{kg}$ of sheep vesicular glands in solution of incubation crystalline $\mathrm{PGE}_{2}(95 \%)$ ratio $k_{\text {cat }} / k_{\text {in }}$

Conversion of arachidonic acid, \%

Reagents and materials, $\mathrm{kg} / \mathrm{kg}$

Wastes, $\mathrm{kg} / \mathrm{kg}$

$$
\begin{gathered}
3-4 \\
2.5 \\
>1000 \\
38-46 \\
4300 \\
2750
\end{gathered}
$$

\begin{tabular}{|c|c|c|c|}
\hline PG & Drug & Drug form & Present use \\
\hline$E_{1}$ & Alprostadil & Solution in alcohol & $\begin{array}{l}\text { Cardiovascular system, } \\
\text { blood storage }\end{array}$ \\
\hline$E_{2}$ & $\begin{array}{l}\text { Dinoprostone } \\
\text { (Prostin E }, \text { Minprostin, } \\
\text { Prostarmon E, Proste- } \\
\text { non) }\end{array}$ & $\begin{array}{l}\text { Solution in alco- } \\
\text { hol, tablets }\end{array}$ & $\begin{array}{l}\text { Obstetrics and gynecolo- } \\
\text { gy, gastrointestinal dis- } \\
\text { orders, bronchospasm, } \\
\text { urinary retention }\end{array}$ \\
\hline $\mathrm{F}_{2 \alpha}$ THAM salt & $\begin{array}{l}\text { Dinoprost } \\
\text { (Prostin } \mathrm{F}_{2 \alpha}, \text { Amoglan- } \\
\text { din, Minprostin } \mathrm{F}_{2 \alpha} \text {, Pro- } \\
\text { starmon F, Prostamo- } \\
\text { din F) }\end{array}$ & Saline solution & $\begin{array}{l}\text { Obstetrics and gynecolo- } \\
\text { gy, urinary retention }\end{array}$ \\
\hline $\mathrm{I}_{2} \mathrm{Na}$ salt & $\begin{array}{l}\text { Epoprostenol sodium } \\
\text { (Cyclo-Prostin) }\end{array}$ & & $\begin{array}{l}\text { Cardiovascular system, } \\
\text { asthma, gastrointestinal, } \\
\text { ocular and renal disor- } \\
\text { ders, gynecology }\end{array}$ \\
\hline
\end{tabular}

Table 4

Clinical use of natural PGs

Clinical use and drug forms. The clinical use of basically studied natural PGs as drugs has been generally accepted $\left[{ }^{4,5}\right]$ and the main fields of their use are presented in Table 4.

The wide range of pharmacological effects and chemical and metabolic instability are the main disadvantages of natural PGs, and there are already about 25 selected analogs for present or potential use [ ${ }^{5}$. However, studies are being conducted on the pharmaceutical preparation of drugs and ways of administration of natural PGs. Instead of a systemic administration, the local one is used, which culminates in the viscous stabile gel of $\mathrm{PGE}_{2}$ for terming labour induction [32]. In case of local use, a 5- to 10-fold decrease in dose and a high specificity of action without any side effects is achieved. Furthermore, suitable solid carrier materials for molecular encapsulation have been found to stabilize the unstable $\mathrm{PGE}_{2}$ (and $\mathrm{I}_{2}$ ) for storage at room temperature. Therefore in certain cases the natural PG drugs are competitive with those prepared on the basis of analogs (for example, the $\mathrm{PGE}_{2}$ gel for cervix ripening $\left[{ }^{32},{ }^{3}\right]$ ).

In cooperation with pharmacologists of Tartu State University we have succeeded in developing the drug «Prostenon» on the basis of $\mathrm{PGE}_{2}$ for introduction and stimulation of labour. Successful clinical trials have been performed in seven clinics (about 800 patients). At present this preparation is being clinically tested for treating renal disorders, asthma and hypertension.

Chemical modification and preparation of derivatives of natural PGs for a potentiation of their biological effects is likewise promising [3, $\left.{ }^{34}\right]$. 


\section{Conclusion}

The appearance of natural PG drugs competitive with those prepared on the basis of analogs has increased the importance of biochemical (bio) synthesis among PG synthetic ways.

At the present technological level with a sufficient enzyme supply, the biochemical synthesis supplemented by chemical methods permits a simple way of preparing natural PGs and their modifications for wide use in certain fields of medicine.

Future research in the whole complex PG area will yield further success in biochemical PG synthesis and wider use of properly modified natural PGs.

\section{REFERENCES}

1. Bergström, S., Danielsson, H., Samuelsson, B. The enzymatic formation of prostaglandin $\mathrm{E}_{2}$ from arachidonic acid. Prostaglandins and related factors 32. Biochim. Biophys. Acta, 1964, 90, 207-210.

2. Van Dorp, D. A., Beerthuis, R. K., Nugteren, D. H., Vonkeman, H. The biosynthesis of prostaglandins. - Biochim. Biophys. Acta, 1964, 90, 204-207.

3. Colbert, I. C. Prostaglandins. Isolation and Synthesis. New York-London, 1973.

4. Martindale. The Extra Pharmacopeia. 28th ed. London, 1982, 1353-1361.

5. Nelson, N. A., Kelly, R. C., Johnson, R. A. Prostaglandins and the arachidonic acid cascade. - Chem. and Eng. News, 1982, 60, 30-44.

6. Wallach, D. P., Daniels, E. G. Properties of a novel preparation of prostagianain synthetase from sheep seminal vesicles. - Biochem. Biophys. Acta, 1971, 231, $445-457$.

7. Yoshimoto, A., Ito, H., Tomita, K. Cofactors requirements of the enzyme synthesizing prostaglandin in bovine seminal vesicles. - Biochem. J., 1970, 68, $487-499$.

8. Ahern, T. J., Katoh, S., Sada, E. Prostaglandin synthesis from arachidonic acid by immobilized ram seminal microsomes. - Biotechnol, and Bioeng., 1983, XXV, $881-885$.

9. Устынюк Т. К., Зеленева Р. Н., Брагинцева Л. М., Максимова Р. А., Полин А. Н. Биосинтез простагландинов из арахидоновой кислоты с помощью грибов класса Deuteromycetes. - В кн.: Синтетические и прикладные исследования простагландинов. Тезисы 2-го Всесоюз. совещ. Уфа, 1984, 17.

10. Брагинцева Л. М., Устынок Т. К., Помазанов В. В., Коваленко В. А., Федорова Н. Ю. Окисление арахидоновой кислоты с помощью липоксигеназы гриба Fusarium Sambucinum. - В кн.: Синтетические и прикладные исследования простагландинов. Тезисы 2-го Всесоюз. совещ. Уфа, 1984, 16.

11. Hemler, M. E., Lands, W. E. M. Evidence for a peroxide-initiated free radical mechanism of prostaglandin biosynthesis. - J. Biol. Chem., 1980, 255, N 13, $6253-6262$.

12. Van der Ouderaa, F. J., Buytenhek, M., Nugteren, D. H., van Dorp, D. A. Acetylation of prostaglandin endoperoxide synthetase with acetylsalicylic acid. Eur. J. Biochem., 1980, 109, 1-8.

13. Van der Ouderaa, F. J., Buytenhek, M., Slikkenveer, F. J., van Dorp, D. A. On the haemoprotein character of prostaglandin endoperoxide synthetase. - Biochim. Biophys. Acta, 1979, 572, $29-43$.

14. De Witt, D. L., Rollins, T. E., Day, J. S., Gauger, J. A., Smith, W. L. Orientation of the active site and antigenic determinants of prostaglandin endoperoxide synthetase in the endoplasmic reticulum. - J. Biol. Chem., 1980, 256, 1037510380 .

15. Ohki, S., Ogino, N., Yamamoto, S., Hayaishi, O. Prostaglandin hydroperoxidase, an integral part of prostaglandin endoperoxide synthetase from bovine vesicular gland microsomes. - J. Biol. Chem., 1979, 254, 829-837.

16. Manson, R. P., Kalyanaraman, B., Tainer, B. E., Eling, T. E. A carbon-centered free radical intermediate in the prostaglandin synthetase oxidation of arachidonic acid. - J. Biol. Chem., 1980, 255, 5019-5022.

17. Мевх А. Т., Вржещ Н. В., Басевич В. Д., Варфоломеев С. Д. Полиферментная система синтеза простагландинов. - В кн.: Химическая и биологическая кинетика. М., 1983, 224-292.

18. Голуб Н. Б., Мевх А. Т., Варфоломеев С. Д. О природе функциональных групп, контролирующих каталитическую активность эндопероксидпростагландинсинтетазы. - Биоорган. хим., 1984, 10, № 2, 268-270. 
19. Мевх А. Т., Голуб Н. Б., Варфоломеев С. Д., Филиппович Е. Н., Макаров В. А.. Евстигнеева P. П. Влияние модификации карбоксильных групп протогемина IX на свойства эндопероксидпростагландинсинтетазы. - Биоорган. хим., 1983, 9, № 8, 1056-1062.

20. Struijk, C. B., Beerthuis, R. K., Pabon, H. J. J., van Dorp, D. A. Specificity in the enzymic conversion of polysaturated fatty acids into prostaglandins. - Rec. Trav. Chim., 1966, 85, 1233-1250.

21. Beerthuis, R. K., Nugteren, D. H., Pabon, H. J. J., van Dorp, D. D. A. Biologically active prostaglandins from some new odd-numbered essential fatty acids. Rec. Trav. Chim., 1968, 87, 461-480.

22. Van Dorp, D. A., Crist, E. J. Specificity in the enzymic conversion of substituted cis-8, cis-11, cis-14 eicisatrienoic acids into prostaglandins. - Rec. Trav. Chim., $1975,94,247-253$.

23. Do, U. H., Sprecher, $H$. Studies on the substrate specificity and inhibition of prostaglandin biosynthesis with methyl branched isomers of eicosa-8,11,14trienoic acid. - J. Lipid Res., 1976, 17, 424-430.

24. Peterson, J. A. The Chemistry of Cytochrome P-450 Catalysed Oxidation Reaction in Fundamental Research in Homogeneous Catalysis, 3. New York-London, $1979,729-750$.

25. O'Connor, D. E., Mihelich, E. D., Coleman, M. C. Stereochemical course of the autoxidative cyclization of lipid hydroperoxides to prostaglandin-like bicycloendoperoxides. - J. Amer. Chem. Soc., 1984, 106, 3577-3584.

26. Egan, R. W., Paxton, J., Kuehl, F. A. Mechanism for irreversible self-deactivation of prostaglandin synthetase. - J. Biol. Chem., 1976, 251, N 23, 7329-7335.

27. Walsh, C. Suicide substrates: mechanism-based enzyme inactivators. - Tetrahedron, $1982,38,871-909$.

28. Bild, G. S., Bhat, S. G., Ramadoss, C. S., Axelrod, B. Biosynthesis of a prostaglandin by a plant enzyme. - J. Biol. Chem., 1978, 253, 21-23.

29. Левин Э. Д., Алаудинов Ш. Т., Черепанова В. Э. Простагландины Е и $_{2} \mathrm{E}_{2}$ живых тканей лиственницы сибирской и тополя бальзамического. - В кн.: Синтетические и прикладные исследования простагландинов. Тезисы 2-го Всесоюз. совещ. Уфа, $1984,7$.

30. Левин Э. Д., Алаудинов Ш. Т., Вол Е. В. Взаимосвязь содержания арахидоновой кнслоты и простагландинов в ходе годового цикла. - В кн.: Синтетические и прикладные исследования простагландинов. Тезисы 2-го Всесоюз. совещ. Уфа, $1984,8$.

31. Майер М., Лилле Ю. Об использовании в биологических исследованиях простагландинов, синтезированных в Институте химии АН ЭССР. - Изв. АН ЭССР. Биол., 1984, 33, № 2, 99-107.

32. Harris, A. S., Kirstein-Pedersen, A., Stenberg, P., Ulmsten, U., Wingerup, $L$. Preparation, characterization and stability of new prostaglandin $\mathrm{E}_{2}$ gel for local administration. - J. Pharmac. Sci., 1980, 69, 1271-1273.

33. Thiery, M., Decoster, J.-M., Parewijck, W., Noah, M. L., Derom, R., Van Kets, H., Defoort, P.. Aertsens, W., Debruyne, G., De Geest, K., Vandererckhove, F. Endocervical prostaglandin $\mathrm{E}_{2}$ gel for preinduction cervical softening-. Prostaglandins, $1984,27,429-439$.

34. Безуглов В. В., Бергельсон Л. Д. Сннтез фторпростациклинов. - Докл. АН CCCP, 1980, 250, 2, 468-469; 1984, 277, 6, 1400-1402.

Academy of Sciences of the Estonian SSR, Institute of Chemistry

Received Nov. 22, 1984

D. $L I L L E$

\section{PROSTAGLANDIINIDE PREPARATIIVNE BIOKEEMILINE SUNTEES JA RAVIMITE VALMISTAMINE}

Artiklis on vaadeldud prostaglandiinide (PG) sünteesi polüeenhapete biokeemilise oksüdatsiooni teel ja ravimite valmistamise võimalusi looduslike PG-de baasil ning analüüsitud andmeid biokatalüsaatori ja reaktsiooni süsteemi kohta, osalevate ensüümide ressursse, preparatiivse protsessi parameetreid ja looduslike PG-de ravivorme ning rakendusi. On järeldatud, et biokeemilise sünteesi lihtsus ja sobivate ravivormide olemasolu loob eeldused looduslike PG-de (eriti $\mathrm{PGE}_{2}$ ) laiaks rakenduseks meditsiinis, eeskätt günekoloogias. 
Ю. ЛИЛЛЕ

\section{ПРИМЕНЕНИЕ ПРОСТАГЛАНДИН-СИНТЕТАЗЫ ДЛЯ ПРЕПАРАТИВНОГО ОКИСЛЕНИЯ ПОЛИЕНОВЫХ КИСЛОТ И ПОЛУЧЕНИЕ ЛЕКАРСТВ НА БАЗЕ ПРОСТАГЛАНДИНОВ}

В статье рассматриваются состояние препаративного биохимического синтеза простагландинов (ПГ) и возможности изготовления лекарственных средств на базе природных ПГ. Параметрами, определяющими эффективность процесса в целом, являются свойства бнокатализатора, условия препаративного процесса, ресурсы ПГ-синтетазы и наличие подходящих лекарственных форм. Простота биохимического синтеза и стабильность лекарственных форм создают предпосылки для широкого применения природных ПГ (особенно ПГЕ 2 ) в медицине, в первую очередь в гинекологии. 